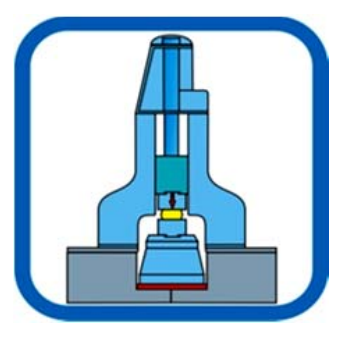

УДК 621.785 .5

\section{РАЗДЕЛ IV \\ ОБОРУДОВАНИЕ И ОСНАСТКА ОБРАБОТКИ ДАВЛЕНИЕМ}

DOI: $10.37142 / 2076-2151 / 2019-2(49) 189$

Дьяченко Ю. Г.

\title{
ОСНОВНІ НАПРЯМКИ ОТРИМАННЯ ЗНОСОСТІЙКИХ ПОКРИТТІВ НА СТАЛЕВИХ ВИРОБАХ ПРИ ДИФУЗІЙНІЙ МЕТАЛІЗАЦЇ̈
}

Процес експлуатації деталей машин і різного інструменту в умовах сухого або рідинного тертя передбачає знос поверхні сполучених деталей. Заміна зношених деталей новими здорожує ремонт і експлуатацію вузлів машин. Тому існує потреба у відновленні машин, що вийшли із ладу деталей, а також їх зміцнення для збільшення терміну експлуатації. Одним 3 видів зміцнення матеріалів є дифузійна металізація як вид хіміко-термічної обробки $[1,2,3]$.

Зносостійкість виробів після дифузійної металізації визначається твердістю і глибиною шару, а у ряді випадків також твердістю основного металу. Твердість шару визначається видом зносу, а глибина - умовами зносу. Передбачати перспективи раціонального використання того або іншого покриття можна в першу чергу по структурі поверхневого шару на всій його глибині. Щільний шар на невеликій глибині, а потім голкоподібний на всій частині, що залишилася, як, приклад, після борування, можна використовувати для деталей, що працюють в умовах абразивного зносу з невеликими контактними навантаженнями, що виключають продавлювання шару, а також що допускають мікронний знос контактуючих поверхонь. При відносно великому зносі контактуючих поверхонь необхідно збільшити глибину суцільної зони поверхневого шару.

В умовах ударно-абразивного зносу необхідно, щоб шар по всій глибині складався 3 твердих зносостійких часток, роз'єднаних між собою м'якою складовою.

В умовах рідинного тертя корисною $є$ наявність мікротріщин в твердому поверхневому шарі контактуючої частини втулки або валу для утримання мастила.

При великому питомому тиску в зоні контактуючих поверхонь необхідно, щоб під зносостійким поверхневим шаром основний метал мав високу твердість, достатню для запобігання продавлюванню шару. Високу твердість металу підповерхневого шару можна забезпечити лише гартуванням. При виборі режимів гартування потрібно унеможливлювати утворення тріщин у поверхневому шарі.

У зв'язку з викладеним, відомі способи борохромування, бороалітування та борохромоалітування аналізуються з позиції їх зносостійкості, будови отримуваних шарів, вживаної термообробки для зміцнення основного металу.

Метою роботи $є$ теоретичний аналіз процесів комплексного нанесення покриттів на металовиробах та виявити оптимальний спосіб одержання зносостійких покриттів у процесі дифузійної металізації.

Для досягнення поставленої мети в роботі вирішувалися наступні задачі:

- проаналізувати способи отримання двокомпонентних і трикомпонентних покриттів у процесі дифузійної металізації на металовиробах з позиції їх зносостійкості;

- виявити складові поверхневого шару, які дозволяють формувати на поверхні металовиробів зносостійкі покриття. 
Для досягнення поставленої мети були проаналізовані літературні дані щодо покриттів, отриманих комплексним насиченням бором, хромом і алюмінієм у різних насичуючих сумішах з позиції їх зносостійкості. Процеси дифузійної металізації розглянуті окремо - борохромування, бороалітування і борохромоалітування.

Особливості процесу борохромування полягають у поліпшенні фізико-хімічних характеристик боридних шарів, що володіють високою крихкістю, недостатньою корозійною стійкістю й жаростійкістю [1-3].

Двокомпонентні шари можуть бути отримані наступними методами: гальванометричним; дифузійним; методом наплавлення; комбінацією об'ємного легування й дифузійного насичення $[4,5]$.

Серед великої кількості методів нанесення двокомпонентних борвміцнюючих покриттів, зацікавленість представляє борохромування у порошках, як найбільш простий і доступний для промислового застосування [6].

Процес борохромування у порошках раціонально проводити з використанням елементів у зв'язаному стані. Це дозволяє знизити реакційну здатність суміші й контролювати процес. При цьому хром локалізується в поверхневих шарах і зміст його істотно залежить від температури процесу [7].

Борохромовані шари, одержувані різними способами, доцільно розділити на три типи: 1) на основі боридів заліза $\left.(\mathrm{Fe}, \mathrm{Cr})_{2} \mathrm{~B},(\mathrm{Fe}, \mathrm{Cr}) \mathrm{B} ; 2\right)$ на основі боридів хрому $(\mathrm{Cr}, \mathrm{Fe})_{2} \mathrm{~B}$, $(\mathrm{Cr}, \mathrm{Fe}) \mathrm{B} ; 3)$ на основі $\alpha$ - твердого розчину хрому й бору в залізі із включеннями боридів. При одночасному насиченні звичайно одержують шари 1-го або 2-го типу, при послідовному частіше утворюються шари 2-го й 3-го типу, при наплавленні струмами високої частоти й гальванотермічному способі - шари 3-го типу. Доцільне використання борохромованих шарів 1-го типу для зміцнення насадок обігрівальних елементів крутильно-витяжних машин (гаряча обробка матеріалів), деталей гідронасосів (гідроабразивне зношування), осей ходових частин екскаватора, пуансонів і матриць прес-форм для виготовлення намиста, штампів (інтенсивне абразивне зношування), деталей технологічного оснащення (зношування в умовах змащення) [8-12].

Зносостійкість борохромованих покриттів більш, ніж в 3 рази вище зносостійкості боридних шарів і більш, ніж в 8 раз вище зносостійкості загартованої й низковідпущеної сталі У8. Зносостійкість борохромованих зразків, виготовлених зі сталі У8, становить 0,8 мг, борованих - 2,6 мг і загартованих з контактного електронагріву з наступним низьким відпустком - 6,7 мг [13].

Робочі поверхні інструмента повинні мати високу твердість і зносостійкість. Сталі 9ХC, ХВГ і Х12М широко застосовують для виготовлення вирубних і карбувальних штампів. Для підвищення ресурсу інструмента хіміко-термічну обробку проводили контактним методом (у порошках) у контейнерах із плавким затвором, у якості якого використовували силікатну брилу. Для досягнення поставленої мети, автори $[14,15]$ застосовували склад насичуючої суміші: $20 \% \mathrm{Cr}, 30 \% \mathrm{~B}_{4} \mathrm{C}, 2 \% \mathrm{NaF}, 48 \% \mathrm{Al}_{2} \mathrm{O}_{3}$. Встановлено, що легування боридів заліза хромом значно підвищує їх твердість і в багатьох випадках - зносостійкість.

Вивчення процесів борування $з$ додатковим легуванням хромом вуглецевих і легованих інструментальних сталей показало, що зі збільшенням вмісту вуглецю глибина дифузійних боридних шарів зменшується. Фазовий склад боридних шарів у всіх сталях однаковий і складається 3 боридів $\mathrm{FeB}$ i $\mathrm{Fe}_{2} \mathrm{~B}$. Однак, при формуванні дифузійного борованого шару в легованих сталях поряд 3 основними боридами $\mathrm{FeB}$ i Fe 2 B можуть спостерігатися й бориди легуючих елементів типу $\mathrm{Cr}_{\mathrm{x}} \mathrm{B}_{\mathrm{y}}$, що пояснюється зустрічною дифузією легуючих елементів 3 матричного $\alpha$ - твердого розчину в поверхневий дифузійний шар. Мета додаткового легування хромом полягає в деякому зниженні загальної твердості боридних шарів $\mathrm{FeB}_{\mathrm{i}} \mathrm{Fe}_{2} \mathrm{~B}$ при одночасному збільшенні їх зносостійкості й зниженні схильності до крихкого руйнування. Проведення комплексного борування дозволяє поліпшити якість боридних шарів [16, 17$]$.

Таким чином, доходимо висновку, що двокомпонентні покриття на виробах, зокрема борохромовані, мають високу зносо-, жаро- і корозійну стійкість, часто вище, ніж у однокомпонентних покриттів, хоча технологія їх одержання при цьому не ускладнюється. Такий висновок дає підставу для більш детального вивчення комплексного насичення поверхні 
сталей одночасно бором і хромом з метою підвищення експлуатаційних характеристик ріжучого й штампового інструмента.

Бороалітування - це процес одночасного або послідовного насичення металів і сплавів бором і алюмінієм. Його застосовують переважно для підвищення жаростійкості й зносостійкості, рідше - корозійної стійкості металів і сплавів. Бороалітування здійснюють різними методами: газовий, у порошках бор-алюміній утримуючих речовин; у пастах і суспензіях; рідкий $[2,3]$.

Серед великої кількості способів нанесення бороалітованого покриття, зацікавленість представляє порошковий, тому що є найбільш простим і екологічно безпечним процесом, що не вимагає застосування спеціального устаткування.

По даним [3], одним з оптимальних режимів бороалітування в порошкових сумішах $\epsilon$ температура $850-1050^{\circ} \mathrm{C}$, тривалість $2-6$ ч. Одночасне насичення бором і алюмінієм можна здійснювати в алюмотермічних сумішах на основі борного ангідриду. Бороалітовані шари формуються при співвідношенні $\mathrm{B}_{2} \mathrm{O}_{3}: \mathrm{Al}=1,85-2: 1-3$. При меншому вмісті алюмінію має місце переважно борування з отриманням боридів $\mathrm{FeB} \mathrm{i} \mathrm{Fe}_{2} \mathrm{~B}$, а при більших - алітування.

Одночасне насичення поверхні хромомолібденової сталі бором і алюмінієм дифузійним порошковим методом утворюються покриття, що складаються із трьох чітко виражених шарів: зовнішній шар з підвищеним вмістом алюмінію, перехідний шар алюміній-залізо й внутрішній шар бор-залізо [18-21].

Бороалітування в 2-15 раз підвищує експлуатаційну стійкість деталей машин, інструмента й технологічного оснащення, що працюють в умовах інтенсивного зношування зі змащенням і без нього [22], у контакті з розплавленими металами, при впливі ударних навантажень, при підвищених і високих температурах, в умовах ерозійного зношування й багаторазових теплозмін (гнучкість, витяжні й вирубні штампи, матриці холодного й гарячого висадження, бандажні ролики волочильних машин) [23].

На підставі аналізу літературних даних доходимо висновку, що бороалітування широко застосовується в машинобудуванні, завдяки широкому спектру одержуваних властивостей шарів бороалітованих покриттів. Однак такі покриття мають ряд недоліків: 1) неможливість застосування покриття при роботі деталей в умовах ударно-абразивного зношування; 2) не захищає вуглецеві сталі від корозії у водяних розчинах солей, лугів і кислот. Тому застосування таких покриттів, у вище зазначених умовах, вимагає додаткових досліджень.

Процес насичення сталевих і чавунних виробів бором, хромом і алюмінієм називається борохромоалітування. Для захисту сталевих виробів, що працюють в умовах тертя, корозійних середовищ, підвищених температур, перспективне використання дифузійних захисних покриттів, що містять бориди хрому. Такі покриття одержують звичайно послідовним насиченням з порошкової суміші спочатку бором, потім хромом, що є економічно невигідно. 3 метою спрощення технології нанесення покриттів була випробувана можливість одержання дифузійних шарів на сталі 45, що містять бориди хрому, при одночасному насиченні бором і хромом шляхом введення в насичуючу суміш алюмінію [24]. Для одержання покриттів застосовували склад, що містить: 40\%...0 В, $0 \ldots 50 \%$ порошок $\mathrm{Cr}, 10 \ldots 25 \% \mathrm{FeAl}, 38 \ldots 13 \% \mathrm{Al}_{2} \mathrm{O}_{3}$ і $2 \% \mathrm{NH}_{4} \mathrm{Cl}$, при температурі процесу $950{ }^{\circ} \mathrm{C}$ і витримкою в печі 5 годин. У результаті досліджень виявлене, що в міру зменшення вмісту бору в суміші, росте активність алюмінію, що приводить до збільшення концентрації його на поверхні шару й товщини шару. Однак бор взаємодіє не тільки з фероалюмінієм, але ще більш активно із хромом. Відсутність бору в суміші приводить до підвищення вмісту хрому в шарі, що викликає зниження концентрації алюмінію на поверхні й зменшення товщини шару.

Алюміній змінює характер взаємодії елементів у газовій фазі й у сталі, що забезпечує одночасну дифузію трьох елементів з отриманням шару, що має гетерофазну структуру дисперсної суміші карбідів і боридів хрому (рис. 1). Виходячи з даних мікроструктурного, рентгенофазного, мікроспектрального аналізу, автори [24] стверджують, що інтерес представляють шари, отримані із сумішей (б) і (в) (рис. 1), вони містять дрібнодисперсну суміш карбідів і боридів (HV 900...1000) на м'якій основі. Результати випробування на зносостійкість показали, що борохромоалітовані шари на сталі 45 в 1, 5 рази перевершують боридні. 


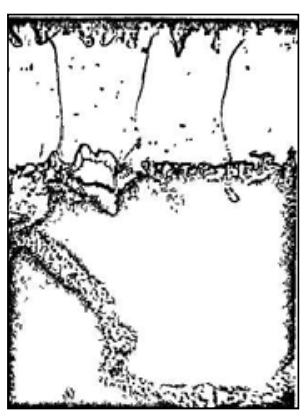

a

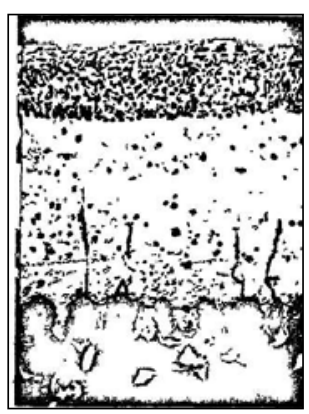

B

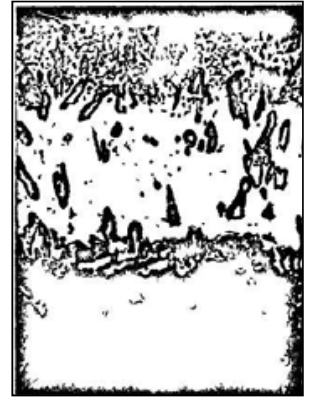

6

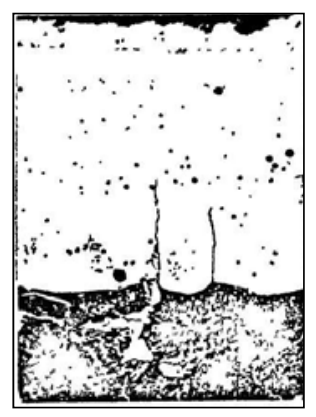

$\Gamma$

Рис. 1. Мікроструктура борохромоалітованих шарів на сталі 45, отриманих із насичуючих сумішей різного складу, $\times 200$ :

$\mathrm{a}-\mathrm{B}-40 \%, \mathrm{Cr}-10 \%$, Feal - $10 \%, \mathrm{Al}_{2} \mathrm{O}_{3}-38 \%, \mathrm{NH}_{4} \mathrm{Cl}-2 \%$; б - B - $30 \%$, $\mathrm{Cr}-20 \%$, Feal $-10 \%, \mathrm{Al}_{2} \mathrm{O}_{3}-38 \%, \mathrm{NH}_{4} \mathrm{Cl}-2 \%$; в $-\mathrm{B}-25 \%, \mathrm{Cr}-25 \%$, Feal $-10 \%$, $\mathrm{Al}_{2} \mathrm{O}_{3}-38 \%, \mathrm{NH}_{4} \mathrm{Cl}-2 \% ; \Gamma-\mathrm{B}-0 \%, \mathrm{Cr}-50 \%$, Feal $-10 \%, \mathrm{Al}_{2} \mathrm{O}_{3}-38 \%, \mathrm{NH}_{4} \mathrm{Cl}-2 \%$

Згідно з результатами, отриманими в роботі [24], можна зробити наступний висновок: процес борохромоалітування $\epsilon$ перспективним для впровадження у виробництво. Однак цей процес недостатньо вивчений і потребує більш поглибленого дослідження, зокрема: 1) відсутні дослідження, що стосуються впливу різних активаторів у складі насичуючої суміші на формування поверхневого шару; 2) відсутні дослідження застосування різних постачальників хрому $\left(\mathrm{FeCr}\right.$ і $\left.\mathrm{Cr}_{2} \mathrm{C}_{3}\right)$ у складі насичуючої суміші; 3) відсутні дослідження впливу термічної обробки на борохромоалітовані шари.

\section{ВИСНОВКИ}

Серед великої кількості методів нанесення покриттів, перспективним є метод одержання дифузійних шарів у порошкових сумішах. Перевагами методу є простота й доступність застосування, оснащення, тобто застосування контейнера із плавким затвором, що виключає порушення екологічної безпеки навколишнього середовища, а також виключається застосування спеціального устаткування.

На підставі аналізу літературних даних, однокомпонентні шари, не дивлячись на ряд переваг, мають недоліки, що полягають у низькій пластичності шарів, невисокій жаро- й корозійній стійкості борованих, невеликій глибині й слабкій спорідненості з основним металом хромованих покриттів. Цей факт обмежує застосування однокомпонентних покриттів у виробництві, особливо якщо мова йде про довговічність деталей машин і різального інструменту в умовах ударно-абразивного зношування.

Двокомпонентні покриття розширюють область застосування шарів, наприклад, легування хромом боридів знижує крихкість останніх. Однак цього недостатньо, тому що борохромовані покриття мають низьку жаростійкість, що визначає експлуатацію при високих температурах. Бороалітування забезпечує жаростійкість виробам, однак не захищає вуглецеві сталі від корозії у водяних розчинах солей, лугів і кислот. Тому двокомпонентні покриття знаходять обмежене застосування в промисловості. 
Уведення до складу порошкової суміші третього компонента дозволить формувати на поверхні виробів зносостійкі покриття з необхідними властивостями. Найбільш перспективним $є$ процес комплексного насичення бором, хромом і алюмінієм, коли є можливість до мінімуму скоротити енергетичні витрати на проведення процесу й одержати максимальний ефект від поліпшення зносостійкості металовиробів.

\section{СПИСОК ВИКОРИСТАНОЇ ЛІТЕРАТУРИ}

1. Ворошнин Л. Г., Ляхович Л. С. Борирование стали. Москва : Металлургия, 1978. 240 с.

2. Борисенок Г. В., Васильев Л. А., Ворошнин Л. Г. и др. Химико-термическая обработка металлов и сплавов: справочник. Москва : Металлургия, 1981. 424 с.

3. Минкевич А. Н. Химико-термическая обработка металлов и сплавов: учебник. Москва : Машиностроение, 1965.492 с.

4. Современные методы упрочнения поверхностей деталей машин: Аналитический обзор. Научнотехнический прогресс в машиностроении / под ред. К. В. Фролова. Москва : ИМАШ АН СССР, 2009.9 .1$. C. 205-271.

5. Заблоцкий В. К. Дьяченко Ю. Г. Влияние активатора на формирование износостойких борохромированных покрытий на инструментальных углеродистых сталях. Надійність інструменту та оптимізаџія технологічних систем. Краматорськ, 2006. № 19. С. 213-217.

6. Гурьев А. М., Гармаева А. Влияние параметров борохромирования на структуру стали и физикомеханические свойства диффузионного слоя. Ползуновский вестник. 2007. № 3. С. 28-34.

7. Степанов М. С., Домбровский Ю. М., Пустовойт В. Н. Диффузионное насыщение углеродистой стали в режиме микродугового нагрева. Металловедение и термическая обработка металлов. 2017. № 1(739). C. 54-57.

8. Степанов М. С., Домбровский Ю. М. Термодинамический анализ реакций формирования карбидного слоя в стали при мнкродуговом насыщении молибденом. Известия высших учебных заведений. Черная металлургия. 2016. Т. 59. № 2. С. 77-81.

9. Домбровский Ю. М., Степанов М. С. Формирование композитного боридного покрытия на стали при микродуговой химико-термической обработке. Известия высших учебных заведений. Черная металлургия. 2015. T. 58. № 3. С. 214-215.

10. Денисюк А. К., Загуляева С. В., Потуткина Е. Н. Структура борированных слоев в углеродистых сталях. Станки и инструмент. 2010. №11. С. 39-40.

11. Гадалов В. Н. Физико-механические, эксплуатационные и релаксационные свойства конструкционных сталей с боридными, цианированными и гальваническими покрытиями. Механика композиционных материалов и конструкций. 2011. Т. 17. № 4. С. 592-598.

12. Лыгденов Б. Д., Мосоров В. И., Мижитов А. Ц. Исследования фазового состава и дефектного состояния градиентных структур борированных сталей 45 и 5ХНВ. Вестник Восточно-Сибирского государственного технологического университета. 2011. № 1. С. 25-31.

13. Бирюков В. П. Изменение свойств борсодержащих покрытий под воздействием лазерным лучом. Вестник машиностроения. 2012. № 1. С. 64-67.

14. Гадалов В. Н. и др. Особенности структуры и свойств боридных диффузионных слоев, оптимизация технологии их получения. Известия ЮЗГУ. Сер. Техника и технология. 2012. 41. № 2. С. 73-77.

15. Ишков Л.В. и др. Боридные покрытия для почвообрабатывающих органов сельхозтехники: получение, структура и износостойкость в реальных условиях. Труды ГОСНИТИ. 2012. 109. Ч. 2. С. 124-131.

16. Гадалов В.Н. Химико-термическая и электрофизическая обработка сплавов и покрытий / В. Н. Гадалов, В. Р. Петренко, А. В. Ляхов. Verlag. Изд-во: LAP- LAMBERT. Германия, 2016. 250 с.

17. Гадалов В. Н. и др. Исследование напряженного состояния в поверхностных слоях доэвтектоидной стали после электролизного борирования. Современные наукоемкие технологии. 2017. № 2. С. 12-16.

18. Гадалов В. Н. и др. Повышение долговечности деталей тяговых цепей конвейеров из конструкционных сталей электролизным борироваиием. Перспективы развития технологий и обработки в машиностроении. Курск : ЮЗГУ, 2017. С. 64-72.

19. Ворошнин Л. Г., Алиев А. А. Борирование из паст. Астрахань : АТТУ, 2006. 287 с.

20. Гвоздев А. Е., Стариков Н. Е., Золотухин В. И. Технология конструкционных и эксплуатационных материалов: учебник / под ред. Гвоздева А. Е. Тула : ТулГУ, 2016. 351 с.

21. Гадалов В. Н. и др. Диффузионные боридные покрытия на железе, сталях и сплавах (с альбомом фотографий). Москва : Курс, 2012. 146 с.

22. Гадалов В. Н. Влияние борсодержащих покрытий на прочностные характеристики сталей / Технология ремонта, восстановления и упрочнения деталей машин, механизмов, оборудования, инструмента и технологической оснастки: материаль 9-й Межд. практич. конф. Санкт-Петербург: Изд-во политехн., ун-та. 2007. Ч. 2. C. $80-87$.

23. Домбровский Ю. М., Степанов М. С. Новые возможности поверхностного легирования стали в порошковых средах. Вестник машиностроения. 2015. № 8. С. 79-81.

24. Косс Е. В., Шевченко И. М., Андрющенко И. И. Борохромоалитирование стали 45. Одесса : ОПИ, Деп. в УкрНИИНТИ 12.09.88, № 2314 Ук88. 1988. 11 с. 


\section{REFERENCES}

1. Voroshnin L.G., Lyakhovich L.S. Boroning of steel. Moscow: Metallurgy. 1978, 240 p. (in Russian).

2. Borisenok G.V., Vasiliev L.A., Voroshnin L.G. et al. Chemical-thermal treatment of metals and alloys. Moscow: Metallurgy. 1981, 424 p. (in Russian).

3. Minkevich A.N. Chemical-thermal treatment of metals and alloys: textbook. Moscow: Mechanical Engineering. 1965, 492 p. (in Russian).

4. Modern methods of hardening the surfaces of machine parts: Analytical review. Scientific and technological progress in mechanical engineering. Ed. K.V. Frolov. Moscow: IMASH. USSR Academy of Sciences. 2009, 9.1, pp. 205-271. (in Russian).

5. Zablotsky V.K., Dyachenko Yu.G. Influence of the activator on the formation of wear-resistant borochromic coatings on tool carbon steels. Instrumentation and optimization of technological systems. Kramatorsk: DSEA. 2006, 19, pp. 213-217. (in Russian).

6. Guryev A.M., Garmaev A. Influence of borochroming parameters on the steel structure and physicomechanical properties of the diffusion layer. Polzunovs Bulletin. 2007, 3, pp. 28-34. (in Russian).

7. Stepanov M.S., Dombrovsky Yu.M., Pustovoit V.N. Diffusion saturation of carbon steel in the microarc heating mode. Metallurgy and heat treatment of metals. 2017, 1 (739), pp. 54-57. (in Russian).

8. Stepanov M.S., Dombrovsky Yu.M. Thermodynamic analysis of the reactions of formation of a carbide layer in steel during multi-arc saturation with molybdenum. Izvestiya. Ferrous Metallurgy. 2016, 59, 2, pp. 77-81. (in Russian).

9. Dombrovsky Yu.M., Stepanov M.S. Formation of a composite boride coating on steel during microarc chemical-thermal treatment. Izvestiya. Ferrous Metallurgy. 2015, 58, 3, pp. 214-215. (in Russian).

10. Denisyuk A.K., Zagulyaeva S.V., Potutkina E.N. The structure of borated layers in carbon steels. Machine tools and tools. 2010, 11, pp. 39-40. (in Russian).

11. Gadalov V.N. Physicomechanical, operational and relaxation properties of structural steels with boride, cyanide and galvanic coatings. Mechanics of composite materials and structures. 2011, 17, 4, pp. 592-598. (in Russian).

12. Lygdsnov B.D., Mosorov V.I., Mizhitov A.Ts. Studies of the phase composition and defective state of the gradient structures of boron steels 45 and 5KHNV. Bulletin of the East Siberian State Technological University. 2011, 1, pp. 25-31. (in Russian).

13. Biryukov V.P. Change in the properties of boron-containing coatings under the influence of a laser beam. Engineering Bulletin. 2012, 1, pp. 64 - 67. (in Russian).

14. Gadalov V.N., et al. Features of the structure and properties of boride diffusion layers, optimization of the technology for their production. Bulletin of the S-WSU. Ser. Technique and technology. Kursk. 2012, 2, 41, pp. 73-77. (in Russian).

15. Ishkov L.V. et al. Boride coatings for tillage organs of agricultural machinery: production, structure and wear resistance in real conditions. Proceedings of GOSNITI. 2012, T. 109, Part 2, pp. 124-131. (in Russian).

16. Gadalov V.N., Petrenko V.R., Lyakhov A.V. Chemical-thermal and electrophysical processing of alloys and coatings. Verlag. Publisher: LAP-LAMBERT. Germany. 2016, 250 p. (in Russian).

17. Gadalov V.N., et al. Investigation of the stress state in the surface layers of hypereutectoid steel after electrolysis boroning. Modern high technology. 2017, 2, pp. 12-16. (in Russian).

18. Gadalov V.N., et al. Increasing the durability of parts of traction chains of conveyors made of structural steels by electrolysis of boron. Prospects for the development of technology and processing in mechanical engineering. Kursk: S-WSU. 2017, pp. 64-72. (in Russian).

19. Voroshnin L. G., Aliiev A.A. Boroning from pastes. Astrakhan: ATTU. 2006, 287 p. (in Russian).

20. Gvozdev A.E., Starikov N.E., Zolotukhin V.I., Sergeev I.I., Sergeev A.I., Breki A.D. Technology of structural and operational materials: a textbook. Ed. A.E. Gvozdev. Tula: Publishing house of TulSU. 2016, 351 p. (in Russian).

21. Gadalov V.N., et al. Diffusion boride coatings on iron, steels and alloys (with an album of photos). Moscow: Course. 2012, 146 p. (in Russian).

22. Gadalov V.N. The effect of boron-containing coatings on the strength characteristics of steels. Proceedings of the 9th Int. practical conf. "Technology of repair, restoration and hardening of machine parts, mechanisms, equipment, tools and industrial equipment". St. Petersburg: Publishing House of the Polytechnic University. 2007, Part 2, pp. 80-87. (in Russian).

23. Dombrovsky Yu.M., Stepanov M.S. New opportunities for surface alloying of steel in powder media. Engineering Bulletin. 2015, 8, pp. 79-81. (in Russian).

24. Koss E.V., Shevchenko I.M., Andryushchenko I.I. Borochromoal steel 45. Dep. in UkrNIINTI 12.09.88, 2314 Uk88. Odessa:OPI. 1988, 11 p. (in Russian).

Дьяченко Ю. Г. - канд. техн. наук, доц. ДДМА.

ДДМА - Донбаська державна машинобудівна академія, м. Краматорськ.

E-mail: dyachenko.yurij.1978@gmail.com 